\title{
KAJIAN PELAKSANAAN PRAKTIKUM KIMIA DI SEKOLAH MENENGAH ATAS DI KABUPATEN LOMBOK BARAT INDONESIA
}

\section{STUDY OF THE IMPLEMENTATION OF CHEMISTRY LABORATORY WORK IN THE SENIOR HIGH SCHOOL IN WEST LOMBOK DISTRICT INDONESIA}

\author{
Eka Junaidi, Saprizal Hadisaputra, Syarifa Wahidah Al Idrus \\ Program Studi Pendidikan Kimia, Fakultas Keguruan dan Ilmu Pendidikan, Universitas Mataram \\ Jalan Majapahit 62 Mataram, 83125, Lombok, Indonesia \\ Email : xjuned@yahoo.com
}

Diterima: 05 Februari 2018. Disetujui: 28 Maret 2018. Dipublikasikan: 31 Maret 2018

\begin{abstract}
Abstrak: Penelitian ini bertujuan untuk melakukan pemetaan terhadap aktivitas praktikum kimia di Sekolah Menengah Atas Negeri se-Kabupaten Lombok Barat Indonesia. Teknik survey (angket dan wawancara) digunakan untuk memperoleh data aktivitas praktikum kimia di sekolah target. Sampel dalam penelitian ini adalah seluruh guru kimia di SMA Negeri Se Kabupaten Lombok Barat yang terdiri dari 14 sekolah. Data yang bersifat kualitatif dianalisis melalui tiga alur yaitu: reduksi data, penyajian data, dan penarikan simpulan atau verifikasi. Berdasarkan hasil analisis data diketahui bahwa di SMAN se Kabupaten Lombok Barat; 1) keadaan sarana dan prasarana laboratorium berkategori 'Baik' dengan nilai rata-rata sebesar 79,20 \%. 2) Tingkat motivasi guru kimia dalam melaksanakan kegiatan praktikum diketahui sekolah dengan kategori 'sedang' dengan nilai rata-rata sebesar 56,70. 3) Keterlaksanaan kegiatan praktikum dan relevansinya dengan materi ajar serta keberhasilan pelaksanaan praktikum berkategori 'Sangat Baik' dengan nilai rata-rata 81,50 \%. 4) Korelasi antara keadaan sarana dan prasarana laboratorium dengan pelaksanaan kegiatan praktikum memiliki nilai koefisien korelasi pearson $=0,316$ (rendah), dengan tingkat signifikansi 0,270 (lebih besar dari 0,05). Korelasi antara motivasi guru untuk melaksanakan praktikum dengan pelaksanaan kegiatan praktikum memiliki nilai koefisien korelasi pearson $=0,169$ (Sangat rendah/hampir tidak ada hubungan), dengan tingkat signifikansi 0,560 (lebih besar dari 0,05) 5). Uji korelasi berganda antara sarana dan prasarana praktikum, motivasi pelaksanakan praktikum terhadap pelaksanaan praktikum dengan koefisien korelasi hanya sebesar 10,90 \%. Hal ini menunjukkan bahwa pelaksanaan kegiatan praktikum dipengaruhi oleh sarana dan prasarana praktikum serta motivasi pelaksanaan praktikum hanya sebesar $10,90 \%$, sedangkan sisanya dipengaruhi oleh faktor lain, dengan nilai signifikasinya sebesar 0,531 (lebih besar dari 0,05). Kesimpulan penelitian ini adalah antara sarana dan prasarana laboratorium dan motivasi pelaksanaan praktikum terhadap pelaksanaan praktikum di sekolah tidak berhubungan secara simultan dan signifikan.
\end{abstract}

Kata Kunci: sarana dan prasarana, motivasi, praktikum kimia, korelasi.

\begin{abstract}
The purpose of this research is to investigate the chemistry practicum activities at the State High School in West Lombok regency Indonesia. Survey techniques (questionnaires and interviews) were used to obtain data on chemical practicum activities in target schools. Samples are all chemistry teachers in SMA Negeri in West Lombok regency consisting of 14 schools. Qualitative data were analyzed through three paths: data reduction, data presentation, and conclusion drawing. The results showed that: 1) the condition of laboratory facilities and infrastructure categorized 'Good', with an average value of 79.20\%. 2) The level of motivation of chemistry teachers in carrying out practicum activities is known as 'Medium' school, with an average value of 56.70. 3) Implementation of practicum activities and their relevance to teaching materials as well as the success of practicum implementation categorized as 'Excellent', with an average value of 81.50\%.4) The correlation between the state of laboratory facilities and infrastructure with the implementation of practicum activities has a correlation coefficient value of Pearson $=0.316$ (low), with significance level of 0.270 . The correlation between teachers' motivation to carry out practicum with the implementation of practicum activity has correlation coefficient value of Pearson $=0,169$ (Very low / no relation), with significance level of 0,560. 5). Multiple correlation test between practicum facilities and infrastructure, practicum implementation motivation on the implementation of the lab with correlation coefficient of only $10.90 \%$. This shows that the implementation of practicum activity is influenced by practicum facilities and practice motivation and practicum is only $10,90 \%$, while the rest is influenced by other factor, with the significance value equal to 0,531 . In conclusion, there is no significant relationship between laboratory facilities and the level of motivation to carry out practicum on the implementation of lab work in school.
\end{abstract}

Keywords: facilities and infrastructure, motivation, chemistry lab, correlation. 


\section{PENDAHULUAN}

Ilmu kimia merupakan ilmu yang diperoleh dan dikembangkan berdasarkan eksperimen yang mencari jawaban atas pertanyaan apa, mengapa, dan bagaimana gejala-gejala alam; khususnya yang berkaitan dengan komposisi, struktur dan sifat, transformasi, dinamika dan energetika zat. Ilmu kimia adalah ilmu yang berbasis teori dan ekperimen. Oleh sebab itu, dalam penilaian dan pembelajaran kimia harus memperhatikan karakteristik ilmu kimia sebagai produk dan proses. Jika dalam proses pembelajaran kimia hanya didominasi oleh teori tanpa adanya praktek maka dapat disimpulkan bahwa tingkat pemahaman siswa pada materi tersebut masih kurang optimal. Melihat karaketristik ilmu kimia tersebut, maka laboratorium tidak dapat dipisahkan dari ilmu kimia. Selain itu, proses pembelajaran kimia yang hanya menekankan pada teori saja tanpa praktek akan cenderung membosankan, kurang diminati dan akhirnya siswa menganggap bahwa pelajaran kimia itu sulit. Selanjutnya banyaknya konsep kimia yang bersifat abstrak yang harus diserap siswa dalam waktu relatif terbatas menyebabkan banyak siswa gagal dalam belajar kimia. Oleh sebab itu butuh sinkronisasi antara pembelajaran teori dan praktek terutama pada pembelajaran kimia di SMA [1-8].

Namun pelaksanaan praktikum kimia pada tingkat SMA memiliki tantangan tersendiri. Selain tingkat kemampuan guru serta motivasi yang dimiliki guru untuk melaksanakan kegiatan praktikum kimia, faktor ketersediaan sarana dan prasarana penunjang kegiatan praktikum kimia juga sangat menentukan keberlangsungan kegiatan praktikum. Tantangan lain adalah ketersediaan anggaran yang memadai terutama untuk pembelian bahan-bahan kimia serta peralatan habis pakai lainnya. Selanjutnya tingkat resiko atau keselamatan kerja dalam pelaksanaan praktikum juga menjadi faktor penentu berlangsungnya kegiatan praktikum. Pengelolaan limbah yang dihasilkan dari kegiatan praktikum kimia tentu juga menjadi pertimbangan penting $[9,10]$. Melihat pentingnya pelaksanaan praktikum dalam pembelajaran kimia serta besarnya kendala kegiatan praktikum kimia terutama di tingkat sekolah menegah atas maka perlu dilakukan pemetaan apakah kegiatan praktikum kimia di SMA Negeri seKabupaten Lombok Barat dapat terlaksana atau tidak.

Berdasarkan hasil studi lapangan, guru di Indonesia masih kurang memanfaatkan kegiatan praktikum sebagai salah satu kegiatan dalam proses belajar mengajar. Kondisi ini disebabkan oleh beberapa hal seperti: 1) Keterampilan guru dalam pelaksanaan kegiatan praktikum dan penggunaan; 2) alat kurang optimal; 3) Petunjuk praktikum yang belum baku sehingga berbeda-beda antar sekolah; 4) Peralatan praktikum yang tersedia tidak mencukupi dari jumlah idealnya bahkan ada yang tidak memilikinya; 5) Kesulitan dalam pengadaan bahan yang diperlukan praktikum; 6) Minimnya tenaga laboran di sekolah, sehingga guru harus bekerja sendiri dalam mempersiapkan praktikum; 7) Alokasi waktu untuk melaksanakan praktikum masih kurang; 8) Pemahaman mengenai pentingnya praktikum dalam mengaplikasikan sains masih kurang $[11,12]$.

Melalui wawancara terhadap beberapa guru kimia SMA di Kabupaten Lombok Barat, terungkap bahwa kegiatan praktikum kadang dilakukan kadang juga tidak bergantung dari materi yang mau dipraktikumkan. Selain dikarenakan motivasi guru untuk melaksanakan kegiatan praktikum, fakta lain juga terungkap bahwa kegitan praktikum dapat dilakukan atau tidak akan sangat bergantung dari kemampuan guru melaksanakannya serta alokasi waktu untuk melaksanakan praktikum masih kurang (ada kekhawatiran guru tidak mampu menyelesaikan target materi sesuai dengan alokasi waktu pembelajaran disekolah jika harus ditambahkan dengan kegiatan praktikum). Selain alasan tersebut di atas ada juga fakta lain yang muncul misalnya bahan dan materi sudah tersedia untuk dilaksanakan kegiatan praktikum namun kendala yang dihadapi adalah ketidakmampuan guru sendiri untuk melaksanakan kegiatan praktikum tersebut. Berdasarkan fakta empiris di atas menunjukkan bahwa kegiatan pelaksaan praktikum kimia pada jenjang SMA Negeri di Kabupaten Lombok Barat masih jarang dilakukan. Namun tidak tertutup kemungkinan masih ada SMA lain yang masih menjalankan kegiatan praktikum secara rutin. Oleh sebab itu, diperlukan pemetaan tentang aktivitas praktikum kimia di SMA Negeri se Kabupaten Lombok Barat untuk mengetahui kondisi riil pembelajaran kimia di Kabupaten Lombok Barat.

Penelitian ini bertujuan untuk (1) Mengkaji keadaan sarana prasarana laboratorium penunjang praktikum kimia, (2) Mengetahui tingkat motivasi guru dan siswa dalam melaksanakan praktikum kimia di SMA Negeri se Kabupaten Lombok Barat. (3) Mengkaji pelaksanaan praktikum yang telah berlangsung. Tujuan tersebut dicapai melalui langkah-langkah penelitian menggunakan penyebaran angket atau kuisioner di SMA Negeri se Kabupaten Lombok Barat. Dari penelitian ini diharapkan akan dihasilkan data primer tentang pelaksanaan kegiatan praktikum di SMA Negeri se Kabupaten Lombok Barat berupa, data kondisi sarana dan prasarana laboratorium penunjang praktikum baik berupa peralatan maupun bahan kimia, tingkat motivasi guru dan siswa dalam melaksanakan praktikum serta keterlaksanaan kegiatan praktikum yang dilakukan di Sekolah, serta solusi alternatif yang dilakukan guru jika kegiatan praktikum kimia tidak berjalan.

\section{METODE PENELITIAN}

Penelitian ini merupakan penelitian menggunakan teknik survey berbentuk angket. Penggunaan metode ini diharapkan mampu 
mengidentifikasi berbagai sebab potensial dari satu efek atau masalah, dan menganalisis masalah yang dihadapi. Masalah akan dipecah menjadi sejumlah kategori yang berkaitan, mencakup sumber daya manusia, Sarana dan prasarana penunjang, Prosedur, motivasi, dan sebagainya. Setiap kategori mempunyai sebab-sebab yang perlu diuraikan melalui sesi brainstorming. Jenis angket/kuisioner pada penelitian ini adalah kuisioner tertutup dengan rating scale. Kuisioner tertutup adalah kuisioner yang sudah disediakan jawabannya sehingga responden hanya memilih sesuai dengan jawaban yang ada dengan memberikan tanda bulat [13]. Sampel dalam penelitian ini adalah seluruh guru kimia di SMA Negeri Se Kabupaten Lombok Barat yang terdiri dari 14 sekolah. Data hasil penelitian survei dianalisis menggunakan teknik deskriptif kuantitatif berupa persentase sederhana, penggunaan tabel, dan gambar. Untuk interpretasi data permasalahan dan kebutuhan menggunakan kriteria: sangat baik, jika $p k>80$ persen; baik, jika 60 persen $<p k \leq 80$ persen; sedang/cukup, jika 40 persen $<p k \leq 60$ persen; kurang, jika 20 persen $<p k \leq 40$ persen; sangat kurang $p k<20$ persen, dimana $p k$ merupakan komponen permasalahan dan kebutuhan kegiatan praktikum. Kemudian data yang bersifat kualitatif dianalisis melalui tiga alur kegiatan sebagaimana yang dikemukakan oleh Miles dan Huberman (1984) , yaitu: (1) reduksi data, (2) penyajian data, (3) penarikan simpulan atau verifikasi [14].

\section{HASIL DAN PEMBAHASAN}

Untuk mengetahui keterkaitan antara keadaan sarana prasarana, motivasi guru dalam melaksanakan kegiatan praktikum terhadap pelaksanaan kegiatan peraktikum di sekolah akan dikaji sebagai berikut.

\section{Keadaan Sarana dan Prasarana Laboratorium}

Berdasarkan angket kuisioner yang diisi oleh guru kimia (86 item) diketahui keadaan sarana dan prasarana laboratorium di sekolah SMAN seKabupaten Lombok Barat (Tabel 1). Berdasarkan data Tabel 1, sarana dan prasarana laboratorium di SMAN se-Kabupaten Lombok Barat masuk kategori Sangat Baik sebanyak 8 sekolah $(57,1 \%)$, kategori Baik sebanyak 5 sekolah (35,7 \%), kategori Cukup sebanyak 1 sekolah $(7,10 \%)$. Secara rata-rata nilai keberadaan sarana dan prasarana laboratorium di SMAN se Kabupaten Lombok Barat meiliki rata-rata 79,20\% yang termasuk dalam kategori Baik.

\section{Tingkat Motivasi Guru Kimia Melaksanakan kegiatan Praktikum di SMAN Se Kabupaten Lombok Barat.}

Tabel 2 menunjukkan skor motivasi guru kimia melaksanakan kegiatan praktikum (20 item butir pertanyaan). Berdasarkan data Tabel 2 dapat diketahui bahwa motivasi guru melaksanakan kegiatan praktikum adalah 3 sekolah dengan Motivasi Tinggi (21,40 \%), 9 sekolah dengan Motivasi Sedang $(64,30 \%)$ dan 2 sekolah dengan Motivasi Rendah $(14,30 \%)$. Secara rata-rata tingkat motivasi melaksanakan kegiatan praktikum di sekolah SMAN se-Kabupaten Lombok Barat memiliki rata-rata sebesar 56,7 yang termasuk dalam kategori sedang.

\section{Pelaksanaan Praktikum di SMAN se Kabupaten Lombok Barat}

Tabel 3 menunjukkan data pelaksanaan praktikum di SMA se kabupatenLombok Barat. Angket kuisioner yang diisi oleh guru kimia berkaitan dengan keterlaksanaan kegiatan praktikum (24 item) diketahui bahwa pelaksanaan kegiatan praktikum yang dilakukan di sekolah SMAN se Kabupaten Lombok Barat menunjukkan bahwa keterlaksanaan praktikum, relevansinya dengan materi ajar serta keberhasilan pelaksanaan praktikum di SMAN Se Kabupaten Lombok Barat masuk kategori Sangat Baik 7 sekolah $(50,00 \%)$, Baik 6 sekolah (42,9,80\%), Cukup 1 sekolah $(7,10 \%)$. Secara rata-rata nilai pelaksanaan praktikum, relevansinya dengan materi ajar serta keberhasilan pelaksanaan praktikum di SMAN se Kabupaten Lombok Barat memiliki rata-rata 81,50 \% yang termasuk dalam kategori Sangat Baik.

\section{Korelasi Antara Sarana Dan Prasarana Laboratorium, Motivasi Melaksanakan Praktikum Terhadap Pelaksanaan Praktikum Di Sekolah}

Untuk mengetahui korelasi antara Sarana dan prasarana laboratorium, motivasi melaksanakan Praktikum terhadap Pelaksanaan Praktikum di Sekolah dilakukan analisis data responden guru kimia di SMAN se Kabupaten Lombok Barat. Tabel 4 menunjukkan korelasi antara sarana dan prasarana laboratorium, motivasi melaksanakan praktikum terhadap pelaksanaan praktikum di sekolah Berdasarkan data hasil analisis statistik Tabel 4 dapat diketahui bahwa ada 3 perihal yang dapat dikorelasikan antara lain: Pertama, korelasi antara Sarana dan Prasarana Laboratorium dengan Pelaksanaan Kegiatan Praktikum memiliki nilai koefisien korelasi pearson $=0,316$ (Rendah) dengan tingkat signifikansi yang lebih besar $(0,271)$ dari 0,05. Hal ini menunjukkan bahwa antara Sarana dan Prasarana Laboratorium dengan Pelaksanaan Kegiatan Praktikum di SMAN se Kabupaten Lombok Barat tidak mempunyai hubungan yang erat. Hal ini dapat diartikan bahwa meskipun Keberadaan Sarana dan Prasarana Laboratorium yang baik akan tetapi tidak ada jaminan keberlangsungan kegiatan pelaksanaan praktikum di sekolah dapat dilakukan. 
Tabel 1. Keadaan Sarana dan Prasarana Laboratorium

\begin{tabular}{|c|c|c|c|c|c|c|c|c|}
\hline \multirow{2}{*}{ No } & \multirow{2}{*}{\multicolumn{2}{|c|}{ NAMA SEKOLAH }} & \multicolumn{6}{|c|}{ Sarana dan Prasarana Laboratorium } \\
\hline & & & R1 & $\mathrm{R} 2$ & R3 & Jumlah & $\%$ & Kriteria \\
\hline 1 & \multicolumn{2}{|c|}{ SMA Negeri 1 Batulayar } & 4 & 22 & 47 & 73 & 84,9 & SB \\
\hline 2 & \multicolumn{2}{|c|}{ SMA Negeri 1 Gunungsari } & 4 & 20 & 26 & 50 & 58,1 & $\mathrm{C}$ \\
\hline 3 & \multicolumn{2}{|c|}{ SMA Negeri 1 Lingsar } & 4 & 22 & 27 & 53 & 61,6 & $\mathrm{~B}$ \\
\hline 4 & \multicolumn{2}{|c|}{ SMA Negeri 1 Narmada } & 4 & 27 & 46 & 77 & 89,5 & SB \\
\hline 5 & \multicolumn{2}{|c|}{ SMA Negeri 2 Narmada } & 4 & 20 & 33 & 57 & 66,3 & $\mathrm{~B}$ \\
\hline 6 & \multicolumn{2}{|c|}{ SMA Negeri 1 Kediri } & 4 & 28 & 28 & 60 & 69,8 & $\mathrm{~B}$ \\
\hline 7 & \multicolumn{2}{|c|}{ SMA Negeri 1 Kuripan } & 4 & 53 & 21 & 78 & 90,7 & SB \\
\hline 8 & \multicolumn{2}{|c|}{ SMA Negeri 1 Labuapi } & 4 & 20 & 51 & 75 & 87,2 & SB \\
\hline 9 & \multicolumn{2}{|c|}{ SMA Negeri 2 Labuapi } & 4 & 29 & 47 & 80 & 93,0 & SB \\
\hline 10 & \multicolumn{2}{|c|}{ SMA Negeri 1 Gerung } & 4 & 26 & 48 & 78 & 90,7 & SB \\
\hline 11 & \multicolumn{2}{|c|}{ SMA Negeri 1 Lembar } & 4 & 29 & 45 & 78 & 90,7 & SB \\
\hline 12 & \multicolumn{2}{|c|}{ SMA Negeri 1 Sekotong } & 4 & 6 & 43 & 53 & 61,6 & $\mathrm{~B}$ \\
\hline 13 & \multicolumn{2}{|c|}{ SMA Negeri 2 Gerung } & 4 & 25 & 47 & 76 & 88,4 & SB \\
\hline \multirow[t]{3}{*}{14} & \multicolumn{2}{|c|}{ SMA Negeri 2 Lembar } & 4 & 23 & 38 & \multirow{3}{*}{$\begin{array}{c}65 \\
68,07 \\
79,2\end{array}$} & \multirow{3}{*}{$\begin{array}{l}75,6 \\
79,2\end{array}$} & $\mathrm{~B}$ \\
\hline & \multicolumn{2}{|c|}{ Rerata } & 4 & 25 & 39,07 & & & \\
\hline & \multicolumn{2}{|c|}{ Persentase $(\%)$} & 100 & 86,2 & 73,7 & & & \\
\hline \multirow[t]{3}{*}{ eterangan } & \multicolumn{8}{|c|}{$\mathrm{R} 1=$ Ruang Laboratorium (4 item) } \\
\hline & $\mathrm{R} 2$ & $=$ Sarana dalan & borat & $\operatorname{lm}(29$ & em) & & & \\
\hline & $\mathrm{R} 3$ & $=$ Alat dan Bah & $53 \mathrm{it}$ & & & & & \\
\hline & SB & $=$ Sangat Baik & $(>$ & & & & & \\
\hline & B & $=$ Baik & $(60$ & $\mathrm{P} \leq 8$ & & & & \\
\hline & $\mathrm{C}$ & $=$ Cukup & $(40$ & $P \leq 6$ & & & & \\
\hline
\end{tabular}

Tabel 2. Motivasi Guru dalam Melaksanakan Praktikum

\begin{tabular}{|c|c|c|c|}
\hline \multirow{2}{*}{ No } & \multirow{2}{*}{ NAMA SEKOLAH } & \multicolumn{2}{|c|}{ Motivasi Guru Melaksanakan Praktikum } \\
\hline & & Motivasi (M) & Kriteria \\
\hline 1 & SMA Negeri 1 Batulayar & 59 & Sedang \\
\hline 2 & SMA Negeri 1 Gunungsari & 56 & Sedang \\
\hline 3 & SMA Negeri 1 Lingsar & 61 & Tinggi \\
\hline 4 & SMA Negeri 1 Narmada & 61 & Tinggi \\
\hline 5 & SMA Negeri 2 Narmada & 55 & Sedang \\
\hline 6 & SMA Negeri 1 Kediri & 56 & Sedang \\
\hline 7 & SMA Negeri 1 Kuripan & 54 & Sedang \\
\hline 8 & SMA Negeri 1 Labuapi & 59 & Sedang \\
\hline 9 & SMA Negeri 2 Labuapi & 61 & Tinggi \\
\hline 10 & SMA Negeri 1 Gerung & 57 & Sedang \\
\hline 11 & SMA Negeri 1 Lembar & 56 & Sedang \\
\hline 12 & SMA Negeri 1 Sekotong & 52 & Rendah \\
\hline 13 & SMA Negeri 2 Gerung & 53 & Rendah \\
\hline 14 & SMA Negeri 2 Lembar & 54 & Sedang \\
\hline & Rata-rata & 56,7 & \\
\hline & Standar Deviasi (SD) & 3,1 & \\
\hline & (Rata-rata + 1SD) & 59,8 & \\
\hline & (Rata-rata - 1SD) & 53,7 & \\
\hline
\end{tabular}

Keterangan : $\quad \mathrm{M}=$ Tingkat Motivasi $\quad \mathrm{SD}=$ Standar Deviasi

Kriteria : $\quad \mathrm{M}>($ Rata-rata $+1 \mathrm{SD}) \quad$ = Tinggi

$($ Rata-rata $-1 \mathrm{SD}) \leq \mathrm{M} \leq($ Rata-rata $+1 \mathrm{SD}) \quad$ = Sedang

$\mathrm{M}<($ Rata-rata $-1 \mathrm{SD}) \quad=$ Rendah 
Tabel 3. Keterlaksanaan Praktikum dan Kesesuaian Materi Praktikum

\begin{tabular}{|c|c|c|c|c|c|c|c|c|}
\hline \multirow{2}{*}{ No } & \multirow{2}{*}{\multicolumn{2}{|c|}{ NAMA SEKOLAH }} & \multicolumn{6}{|c|}{ Pelaksanaan Praktikum } \\
\hline & & & $\mathrm{T} 1$ & $\mathrm{~T} 2$ & T3 & Jumlah & $\%$ & Kriteria \\
\hline 1 & \multicolumn{2}{|c|}{ SMA Negeri 1 Batulayar } & 7 & 3 & 9 & 19 & 79,2 & $\mathrm{~B}$ \\
\hline 2 & \multicolumn{2}{|c|}{ SMA Negeri 1 Gunungsari } & 9 & 3 & 7 & 19 & 79,2 & B \\
\hline 3 & \multicolumn{2}{|c|}{ SMA Negeri 1 Lingsar } & 10 & 3 & 6 & 19 & 79,2 & B \\
\hline 4 & \multicolumn{2}{|c|}{ SMA Negeri 1 Narmada } & 9 & 3 & 7 & 19 & 79,2 & $\mathrm{~B}$ \\
\hline 5 & \multicolumn{2}{|c|}{ SMA Negeri 2 Narmada } & 10 & 3 & 8 & 21 & 87,5 & SB \\
\hline 6 & \multicolumn{2}{|c|}{ SMA Negeri 1 Kediri } & 9 & 5 & 7 & 21 & 87,5 & SB \\
\hline 7 & \multicolumn{2}{|c|}{ SMA Negeri 1 Kuripan } & 10 & 3 & 8 & 21 & 87,5 & SB \\
\hline 8 & \multicolumn{2}{|c|}{ SMA Negeri 1 Labuapi } & 7 & 3 & 8 & 18 & 75,0 & $\mathrm{~B}$ \\
\hline 9 & \multicolumn{2}{|c|}{ SMA Negeri 2 Labuapi } & 10 & 5 & 8 & 23 & 95,8 & SB \\
\hline 10 & \multicolumn{2}{|c|}{ SMA Negeri 1 Gerung } & 10 & 3 & 7 & 20 & 83,3 & SB \\
\hline 11 & \multicolumn{2}{|c|}{ SMA Negeri 1 Lembar } & 9 & 3 & 9 & 21 & 87,5 & SB \\
\hline 12 & \multicolumn{2}{|c|}{ SMA Negeri 1 Sekotong } & 8 & 3 & 7 & 18 & 75,0 & $\mathrm{~B}$ \\
\hline 13 & \multicolumn{2}{|c|}{ SMA Negeri 2 Gerung } & 10 & 3 & 8 & 21 & 87,5 & SB \\
\hline \multirow[t]{3}{*}{14} & \multicolumn{2}{|c|}{ SMA Negeri 2 Lembar } & 5 & 3 & 6 & 14 & \multirow{3}{*}{$\begin{array}{l}58,3 \\
81,5\end{array}$} & $\mathrm{C}$ \\
\hline & \multicolumn{2}{|c|}{ Rerata } & 8,79 & 3,29 & 7,50 & 19,57 & & \\
\hline & \multicolumn{2}{|c|}{ Persentase $(\%)$} & 87,9 & 65,7 & 83,3 & 81,5 & & \\
\hline \multirow[t]{3}{*}{ Keterangan : } & $: \quad \mathrm{T} 1$ & $=$ Keterlaksan & xum (1 & tem) & & & & \\
\hline & $\mathrm{T} 2$ & $=$ Relevansi de & eri Aja & 5 item & & & & \\
\hline & $\mathrm{T} 3$ & $=$ Keberhasilar & aan $\mathrm{Pr}$ & tikum & item) & & & \\
\hline \multirow[t]{3}{*}{ Kriteria : } & SB & $=$ Sangat Baik & $(>$ & $\%)$ & & & & \\
\hline & B & $=$ Baik & $(60$ & $\mathrm{KR} \leq$ & & & & \\
\hline & $\mathrm{C}$ & $=$ Cukup & $(40$ & $\mathrm{KR} \leq$ & & & & \\
\hline
\end{tabular}

Tabel 4. Hasil Anasisis Statistik Korelasi Pearson Antara Sarana dan Prasarana Laboratorium, Motivasi Melaksanakan Praktikum Terhadap Pelaksanaan Praktikum

\begin{tabular}{llccc}
\hline Keterangan & Korelasi Pearson & $\begin{array}{c}\text { Sarana dan Prasarana } \\
\text { Laboratorium }\end{array}$ & $\begin{array}{c}\text { Motivasi } \\
\text { Melaksanakan } \\
\text { Praktikum }\end{array}$ & $\begin{array}{c}\text { Pelaksanaan } \\
\text { Praktikum }\end{array}$ \\
\hline Sarana dan & Signifikansi & 1 & 0,244 & 0,316 \\
Prasarana & $\mathrm{N}$ & 14 & 0.401 & 0,271 \\
Laboratorium & Korelasi Pearson & 0,244 & 14 & 14 \\
Motivasi & Signifikansi & 0,401 & 1 & 0,169 \\
Melaksanakan & $\mathrm{N}$ & 14 & 14 & 0,565 \\
Praktikum & Korelasi Pearson & 0,316 & 0,169 & 14 \\
Pelaksanaan & Signifikansi & 0,271 & 0,565 & 1 \\
Praktikum & $\mathrm{N}$ & 14 & 14 & 14
\end{tabular}

Sumber : Pengolahan Data Sekunder

Kriteria korelasi Pearson :

$$
\begin{array}{lll}
0 & -0,20 & =\text { Sangat Rendah (hampir tidak ada hubungan) } \\
0,21- & -0,40 & =\text { Rendah } \\
0,41 & -0,60 & =\text { Sedang } \\
0,61- & -0,80 & =\text { Cukup Tinggi } \\
0,81 & -1 & =\text { Tinggi }
\end{array}
$$


Tabel 5. Hasil Analisis Korelasi Berganda Sarana Dan Prasaran Laboratorium, Motivasi Melaksanakan Praktikum Dengan Pelaksanaan Praktikum

\begin{tabular}{|c|c|c|c|c|c|c|c|c|}
\hline \multicolumn{9}{|c|}{ Model Summary } \\
\hline \multirow[b]{2}{*}{ Model } & \multirow[b]{2}{*}{$\mathrm{R}$} & \multirow[b]{2}{*}{$\begin{array}{c}\mathrm{R} \\
\text { Square }\end{array}$} & \multirow[b]{2}{*}{$\begin{array}{l}\text { Adjusted R } \\
\text { Square }\end{array}$} & \multirow[b]{2}{*}{$\begin{array}{l}\text { Std. Error of the } \\
\text { Estimate }\end{array}$} & \multicolumn{4}{|c|}{ Change Statistics } \\
\hline & & & & & $\begin{array}{l}\text { R Square } \\
\text { Change }\end{array}$ & F Change df1 & df2 & $\begin{array}{l}\text { Sig. F } \\
\text { Change }\end{array}$ \\
\hline 1 & $.330^{\mathrm{a}}$ & .109 & -.053 & 2.19420 & 109 & .672 & 11 & .531 \\
\hline a. Predi & ctors: ( & Constan & Motivasi, & rana dan Prasara & & & & \\
\hline
\end{tabular}

Pada penelitian ini diperoleh informasi bahwa pelaksanaan kegiatan praktikum yang dilakukan di sekolah tidak selalu dapat dilakukan untuk semua materi yang diajarkan. Hal ini diduga disebabkan oleh ketidaksesuaian bahan yang tersedia di laboratorium dengan materi pelajaran yang akan dipraktikumkan. Selain itu fakta lain yang juga dapat digambarkan adalah meskipun keberadaan alat alat yang akan dipergunakan untuk kegiatan praktikum tergolong 'Baik' akan tetapi kegiatan praktikum tidak seluruhnya dapat dilaksanakan (hal ini diduga disebabkan oleh keterbatasan kemampuan sumber daya manusia serta manajemen laboratorium yang ada di sekolah). Meskipun demikian dalam penelitian ini juga diperoleh informasi bahwa walaupun pelaksanaan kegiatan praktikum tidak seluruhnya dapat dilaksanakan tetapi guru memiliki alternatif lain dalam pembelajaran sebagai pengganti praktikum seperti laboratorium virtual maupun kimia komputasi, walaupun kedua alternatif tersebut masih sangat jarang bisa dilakukan oleh guru.

Kedua, Berdasarkan hasil analisis statistik diatas juga menyimpulkan korelasi antara Motivasi guru untuk melaksanakan praktikum dengan Pelaksanaan Kegiatan Praktikum dengan sebesar 0,169 (sangat rendah/hampir tidak ada hubungan). Korelasi tersebut menunjukkan bahwa antara Motivasi guru untuk melaksanakan praktikum dengan Pelaksanaan Kegiatan Praktikum tidak saling berkorelasi. Hal ini diduga disebabkan karena beberapa faktor diantaranya: a). Materi pembelajaran di sekolah yang jumlahnya banyak menyebabkan tidak mungkin dilakukan praktikum seluruhnya, b). Adanya anggapan Guru bahwa melaksanakan kegiatan praktikum membutuhkan waktu yang lama yang akan mengakibatkan jam mengajar guru berkurang, c). Keberadaan buku panduan praktikum di sekolah belum memadai atau tidak sesuai dengan kebutuhan praktikum, d). Kemampuan guru dalam menghubungkan antara materi pembelajaran teoritis untuk dipraktikumkan relatif masih kurang sehingga pelaksanaan kegiatan praktikum dianggap hanya formalitas saja, e). Kemampuan guru mengelola kegiatan praktikum masih kurang sehingga guru sendiri tidak yakin dengan apa yang harus dilakukan dalam praktikum tersebut, serta f). Guru juga merasa dalam kegiatan praktikum siswa akan lebih sulit dikontrol karena dalam praktikum harus ada pengawasan dalam pelaksanaan praktikum tersebut. Oleh karena alasan-alasan tersebut di atas maka dianggap perlu dilakukan tindakan perbaikan terutama berkaitan dengan mengubah persepsi guru terhadap pelaksanaan praktikum disekolah misalnya adanya pelatihan manajemen laboratorium, standarisasi prosedur praktikum, pelatihan penggunaan alat-alat dan penanganan bahan praktikum.

Ketiga, berdasarkan hasil analisis data (model summary) pada Tabel 5, diperoleh informasi korelasi antara Sarana dan Prasarana Praktikum, Motivasi Pelaksanakan Praktikum terhadap Pelaksanaan Praktikum dengan koefisien korelasi (R Square) hanya sebesar 10,9\%. Hal ini menunjukkan bahwa Pelaksanaan kegiatan Praktikum dipengaruhi oleh Sarana dan Prasarana Praktikum serta Motivasi pelaksanaan Praktikum hanya sebesar 10,9\%, sedangkan sisanya dipengaruhi oleh faktor lain. Untuk mengetahui tingkat signifikansi koefisien korelasi ganda diuji secara keseluruhan. Berdasarkan data di atas diperoleh nilai signifikansinya sebesar 0,531 . Karena nilai signifikansinya lebih besar dari 0,05 artinya antara Sarana dan Prasarana Laboratorium dan Motivasi Pelaksanaan Praktikum tidak berhubungan secara simultan dan signifikan terhadap Pelaksanaan Praktikum di Sekolah.

\section{KESIMPULAN}

Berdasarkan hasil kajian dalam penelitian ini dapat diambil kesimpulan sebagai berikut:

1. Keberadaan Sarana dan Prasarana Laboratorium di SMAN Se Kabupaten Lombok Barat masuk kategori Sangat Baik sebanyak 8 sekolah $(57,10 \%)$, kategori Baik sebanyak 5 sekolah (35,70\%), kategori Cukup sebanyak 1 sekolah $(7,10 \%)$. Secara rata-rata nilai keberadaan sarana dan prasarana laboratorium di SMAN se Kabupaten Lombok Barat meiliki rata-rata 79,20\% yang termasuk dalam kategori Baik. 
2. Tingkat motivasi guru kimia SMAN se Kabupaten Lombok Barat dalam melaksanakan kegiatan praktikum adalah 3 sekolah dengan Motivasi Tinggi $(21,40 \%), 9$ sekolah dengan Motivasi Sedang $(64,30 \%)$ dan 2 sekolah dengan Motivasi Rendah (14,30 $\%)$. Secara rata-rata tingkat motivasi melaksanakan kegiatan praktikum di sekolah SMAN se-Kabupaten Lombok Barat memiliki rata-rata sebesar 56,7 yang termasuk dalam kategori sedang.

3. Keterlaksanaan praktikum, relevansinya dengan materi ajar serta keberhasilan pelaksanaan praktikum di SMAN Se Kabupaten Lombok Barat masuk kategori Sangat Baik 7 sekolah $(50,00 \%)$, Baik 6 sekolah $(42,9,80 \%)$, Cukup 1 sekolah $(7,10$ $\%)$ Secara rata-rata nilai pelaksanaan praktikum, relevansinya dengan materi ajar serta keberhasilan pelaksanaan praktikum di SMAN se Kabupaten Lombok Barat memiliki rata-rata $81,50 \%$ yang termasuk dalam kategori Sangat Baik.

4. Korelasi antara Sarana dan Prasarana Laboratorium dengan Pelaksanaan Kegiatan Praktikum memiliki nilai koefisien korelasi pearson $=0,316$ (rendah), dengan taraf signifikansi sebesar 0,271 (lebih besar dari 0,05). Sedangkan antara Motivasi guru untuk melaksanakan praktikum dengan Pelaksanaan Kegiatan Praktikum memiliki nilai koefisien korelasi pearson $=0,169$ (sangat rendah/hampir tidak ada hubungan), dengan taraf signifikansi sebesar 0,565 (lebih besar dari 0,05).

5. Untuk uji korelasi berganda antara Sarana dan Prasarana Praktikum dengan Motivasi Pelaksanakan Praktikum terhadap Pelaksanaan Praktikum dengan koefisien korelasi (R Square) hanya sebesar $10,9 \%$, sedangkan sisanya dipengaruhi oleh faktor lain, dengan taraf signifikansi sebesar 0,531 (lebih besar dari 0,05). Hal ini berarti bahwa antara Sarana dan Prasarana Laboratorium dan Motivasi Pelaksanaan Praktikum tidak berhubungan secara simultan dan signifikan terhadap Pelaksanaan Praktikum di Sekolah.

\section{SARAN}

Berdasarkan temuan di atas, saran yang perlu mendapatkan perhatian dalam kajian ini adalah pertama, perlu dilakukan tindakan perbaikan terutama berkaitan dengan mengubah persepsi guru terhadap pelaksanaan praktikum disekolah misalnya adanya pelatihan manajemen laboratorium, standarisasi prosedur praktikum, pelatihan penggunaan alat-alat dan penanganan bahan praktikum. Kedua, perlunya memperkenalkan solusi alteratif pengganti praktikum kimia di SMA untuk memaksimalkan proses pembelajaran kimia di sekolah sebagai alternatif pengganti praktikum (laboratorium basah) seperti laboratorium virtual maupun kimia komputasi

\section{UCAPAN TERIMAKASIH}

Terimakasih yang sebesar-besarnya disampaikan kepada Universitas Mataram yang telah mendukung penelitian ini melalui Sumber Dana DIPA BLU PNBP Tahun 2017 no kontrak: 787M/UN.18/LPPM/2017.

\section{DAFTAR PUSTAKA}

1. Junaidi, E., Hadisaputra, S., Hakim, A., \& Al Idrus, S. W. (2017). Kajian Pelaksanaan Praktikum Kimia Di Sekolah Menengah Atas Negeri Se Kabupaten Lombok Tengah. Jurnal Ilmiah Profesi Pendidikan, 2(1), 101-111.

2. Rahman, D., Adlim, A., \& Mustanir, M. (2017). Analisis Kendala Dan Alternatif Solusi Terhadap Pelaksanaanpraktikum Kimia Pada Slta Negeri Kabupaten Aceh Besar. Jurnal Pendidikan Sains Indonesia, 3(2), 01-13.

3. Wiratma, I. G. L. (2015). Pengelolaan Laboratorium Kimia pada SMA Negeri di Kota Singaraja:(Acuan Pengembangan Model Panduan Pengelolaan Laboratorium Kimia Berbasis Kearifan Lokal Tri Sakti). JPI (Jurnal Pendidikan Indonesia), 3(2).

4. Ningsyih, S., Junaidi, E., \& Al Idrus, S. W. (2016). Pengaruh Pembelajaran Praktikum Berbasis Inkuiri Terbimbing Terhadap Kemampuan Berpikir Kritis Dan Hasil Belajar Kimia Siswa. Jurnal Pijar Mipa, 11(1).

5. Aprianti, R., Wildan, W., \& Muntari, M. (2011). Pengembangan Modul Pembelajaran Larutan Asam Basa Berbasis Pendekatan MMS (Makroskopik Mikroskopik Simbolik) dan Implementasinya dalam Pembelajaran. Jurnal Pijar Mipa, 6(1).

6. Hakim, A., Kadarohman, A., \& Syah, Y. M. (2015). Making a natural product chemistry course meaningful with a mini project laboratory. Journal of Chemical Education, 93(1), 193-196.

7. Hakim, A., Liliasari, L., Kadarohman, A., \& Syah, Y. M. (2016). Improvement of Student Critical Thinking Skills with the Natural Product Mini Project Laboratory Learning. Indonesian Journal of Chemistry, 16(3), 322-328. 
8. Anwar, Y. A. S., \& Senam, S. (2017). Effective Laboratory Work in Biochemistry Subject: Students' and Lecturers' Perspective in Indonesia. International Journal of Higher Education, 6(2), 100.

9. Coppola, B. P. (2008). Selamat datang di Indonesia: Learning about chemistry and chemistry education in Indonesia. Journal of chemical education, 85(9), 1204.

10. Hadisaputra, S., Savalas, L. R. T., \& Hamdiani, S. (2017). Praktikum Kimia Berbasis Kimia Komputasi Untuk Sekolah Menengah Atas. Jurnal Pijar Mipa, 12(1).

11. Anwar, Y. A. S., Senam, \& Laksono, E. W. (2017, August). Identification of the students' critical thinking skills through biochemistry laboratory work report. In AIP Conference Proceedings (Vol. 1868, No. 1, p. 030013). AIP Publishing.

12. Utomo, M. P. (2011). Adaptasi Pelaksanaan Praktikum Kimia Negara OECD. Makalah disampaikan Pada PPM Unggulan berjudul Adaptasi Kurikulum Kimia SMA Bertaraf Internasional terhadap Kurikulum dari Negara OECD, di FMIPA UNY, 4.

13. Suharsimi, A. (2006). Prosedur penelitian suatu pendekatan praktik. Jakarta: Rineka Cipta.

14. Miles, M. B., \& Huberman, A. M. (1984). Qualitative data analysis: A sourcebook of new methods. In Qualitative data analysis: a sourcebook of new methods. Sage publications. 